\title{
An Investigation into Anxiety about the Science Lesson Through a Mixed Model
}

\author{
Emrah Özbuğutu ${ }^{1}$ \\ ${ }^{1}$ Faculty of Education, Siirt University, Siirt, Turkey \\ Correspondence: Emrah Özbuğutu, Faculty of Education, Siirt University, Siirt, 561000, Turkey. E-mail: \\ emrahozbugutu@hotmail.com
}

Received: December 20, 2020 Accepted: January 23, 2021 Online Published: January 26, 2021

doi:10.5539/jel.v10n1p104 URL: https://doi.org/10.5539/jel.v10n1p104

\begin{abstract}
This study was conducted with a total of 158 students from 6th, 7th and 8th grades in two different secondary schools located in Siirt in the academic year of 2020-2021 to examine students' anxiety about the science lesson in terms of various variables and to determine the reasons for science anxiety. The study was conducted on the basis of a mixed design. While quantitative data were collected using the "Science Anxiety Scale (SAS)" and qualitative data were collected using the "Anxiety Form". Through the SAS, the anxiety levels of the students were determined and the relationship between the scale anxiety score and gender, grade levels, income levels and type of school was examined. The data collected by the SAS were analysed using the SPSS 26 package program. The content analysis of the data collected with the anxiety form was carried out. It was determined in the quantitative part of the research that there is no significant relationship between science anxiety and gender, 6th-grade students have higher science anxiety in the environmental sub-dimension compared to 7 th and 8th-grades, and there is a significant relationship between family income level and type of school and anxiety scores, science anxiety decreased as the income level increased, and students studying at private school had less science anxiety. Based on the qualitative data of the study, anxieties of the study are mainly related to the science lesson, notably related to the exam, rote learning, hardness of lessons, the anxiety of falling behind in the class, and the homework. However, while some students have anxiety about the attitude and questions of teachers, others are instinctively anxious about giving wrong or no answers arising from attitudes and morale. While 3\% of the students are anxious about everything, $14.9 \%$ are anxious about nothing. Their responses to the items of the questionnaire and the anxiety form are close in proportion, so it has been concluded that the quantitative and qualitative data of the study support each other.
\end{abstract}

Keywords: science lesson, anxiety, secondary school students, science anxiety scale

\section{Introduction}

Anxiety is used to express emotions and experiences that occur in some period of life. In a broad sense, this personal reaction to cases in which a person is worried about experiencing a bad situation in the future and in which a person feels insecure means forward-looking anxiety, inability to make a decision, complexity, negative thinking, and hopelessness, and causes the relevant person to fail in life. Anxiety can take different forms in each individual. Anxiety is a feeling that disturbs the individual in daily life and is seen as a cause of disharmony in school life by significantly affecting the person's movements (Hill \& Sarason, 1966; Deveci, Çalmaz, \& Açık, 2012). It is observed that people experience significant problems due to anxiety, which is thought to cause important problems in school education.

Anxiety is one of the most important factors affecting the school life of the student. While past experiences and type of anxiety whose result is still continuing causes the student to fail, the short-term anxiety affects the success positively. Laukenmann et al. (2003) stated in their study that successful and unsuccessful students were anxious about the physics lesson and students who were more successful had anxiety about being unable to understand the subject, and students who were not successful had anxiety about failing the exam. Eddy (2000) grouped chemistry anxiety into anxiety about chemistry, learning, evaluation, and chemicals and stated that students with low anxiety levels were more successful in a chemistry class than others. Şahin (2000) also defined the mathematics lesson anxiety that prevents success as being anxious and nervous while solving mathematical questions in normal life and school life (Sağır, 2014). 
It has been determined that anxiety has a crucial role in learning activities and anxiety level increases learning unless it is in excessive amount, whereas excessive anxiety affects learning in the opposite direction (Morgan, 1991; Oğuz \& Karakuş, 2017). As a result, it can be said that a low anxiety level motivates learning and being successful, while excessive anxiety is an important factor of failure.

Science anxiety is the fear of the science lesson that many students experience today. According to Mallow (1988), this fear causes individuals not to learn the subject and to think negatively about the lesson. According to Oludipe and Awokoy (2010), anxiety about science lessons is also defined as an uneasiness factor that damages self-esteem. It is observed that anxious students have more difficulty in learning (Say \& Uçak, 2019). People's adaptation to the rapidly advancing developments, following and assimilating the developments in science and technology, and using them in normal life through science are essential requirements in all societies. Science lessons that aim to learn by doing and experiencing also enable students to develop in terms of cognitive features. Therefore, schools should lay stress on science teaching in schools (Hazır, 2006). It is also thought that student success increases if the anxieties of the students are determined during the teaching of science lessons and an education free of anxiety is given. More and result-oriented studies need to be done in relation to the science lesson.

\subsection{Objective}

In the qualitative part of the study, the objective to reveal the causes of the anxiety of the students, and in the quantitative part, the objective was to reveal the relationship between anxiety situations and gender, grade level, economic status of the family, and type of school. For this purpose, six sub-problems were determined and answers were sought for these problems.

\subsection{Sub-Problems}

1) What are the science anxieties of students?

2) Is there a relationship between science anxiety scores and the gender of the students?

3) Is there a relationship between science anxiety scores and grade levels of the students?

4) Is there a relationship between science anxiety scores and the family income level of the students?

5) Is there a relationship between their science anxiety scores and type of school?

6) What are the anxieties about the science lesson of the students?

\section{Method}

A mixed design was used in this study to answer the questions of the research. In this study of descriptive type, quantitative data were collected using the "Science Anxiety Scale (SAS)". Through the SAS, the relationship between students' anxiety levels and gender, the class, the income level of the family, and type of school were examined. The qualitative data of the study were collected with the "Anxiety Form" consisting of a single question. The data collected with the scale were analyzed with the SPSS 26 package program. While The Mann-Whitney u test was used for two different variables, the Kruskal-Wallis $\mathrm{H}$ test was used for more than two variables. To understand the direction of the difference in the Kruskal-Wallis H test results, the Mann-Whitney $\mathrm{U}$ test was conducted between pairs.

The data collected with the anxiety form were analyzed by content analysis. As a result of the analysis, codes and themes were formed based on them.

\subsection{Data Collection Tools}

In the study, the Science Anxiety Scale (SAS) and the Anxiety Form were used to determine the causes of anxiety.

\subsubsection{Science Anxiety Form}

The Science Anxiety Scale developed by Güzeller and Doğru (2011) was used in the study. Consisting of 28 items, this form is a 5-Likert type scale. The questionnaire form is structured as "Strongly Disagree", "Disagree", "Somewhat Agree", "Agree", "Strongly Agree". It is scored from 5 to 1 from "Strongly Agree" to "Strongly Disagree." Similarly, it is also scored from 5 to 1 for negative items in the questionnaire. The reliability coefficient (Cronbach alpha coefficient) related to the sub-dimension was found to be .43 , the reliability coefficient related to the environmental factors sub-dimension as 67 , and the reliability coefficient related to the whole of the scale as .63. The items $6,11,12,16$, and 26 were removed from the scale as they were found to decrease the reliability of the scale to put the scale into final form. After removing the questions, the reliability coefficient related to the personal factors dimension, the reliability coefficient related to the environmental 
factors sub-dimension, and the reliability coefficient related to the whole scale were found to be $.75, .67$, and .83 , respectively. The lowest and highest scores to be obtained are 18 and 90 for the personal factors sub-dimension, 5 and 25 for the environmental factors sub-dimension, and 23 and 115 for the whole questionnaire. The personal factors sub-dimension of the scale consists of 18 items and personal effects such as nervousness, tension, stress, fear, and anxiety. The environmental factors sub-dimension consists of 5 items and environmental effects such as teacher, TV, sleep, and curriculum.

\subsubsection{The Anxiety Form and Demographic Information}

To reach the demographic information of the students, questions were asked to determine 4 items including gender, grade level, the economic level of the family, and type of school.

To determine the students' anxiety about the science lesson, a form consisting of a single open-ended question-What makes you anxious most about the science lesson? Why? - was used (Uçak \& Say, 2019). While using this form, the necessary expert opinions on the subject were taken and it was concluded that the content validity was provided. Before data was collected, each branch was informed by the teacher who applied the questionnaire. Through this information, there is a text consisting of definitions and examples of anxiety. Therefore, it was understood from the students what is meant by anxiety. Finally, the students were asked to respond to the form.

\subsection{Data Collection and Study Group}

To collect data of the study, the Science Anxiety Scale (SAS) developed by Güzeller and Doğru (2011), a form consisting of a single question for determining science anxieties and 4 questions aiming to determine demographic characteristics as data collection tools printed and reproduced on a single paper. In line with the purpose of the study, the SAS was applied to a total of 158 students in the 6th, 7th and 8th grades, one in the state and the other in a private school located in the province of Siirt during the first semester of the academic year of 2020-2021. One of the schools is a private school in the city centre of Siirt and the other is a village secondary school in the district. The distribution of the participating students according to gender, type of school, grade level and the financial status of their families is given in Table 1. Necessary ethics committee permissions were obtained for the study and the students were warned to respond sincerely and not to write names, adding that the collected data would be analyzed in a legal framework. They were given 30 minutes to answer the scales and the same situation was repeated for each class.

Table1. Demographic information

\begin{tabular}{lll}
\hline Gender & Number of students & Percentage \\
\hline Female & 79 & 50 \\
Male & 79 & 50 \\
Type of school & & \\
Public school & 88 & 55.7 \\
Private school & 70 & 44.3 \\
Class & & \\
6th grade & 49 & 31 \\
7th grade & 53 & 33.5 \\
8th grade & 56 & 35.5 \\
Economic Status & & \\
Under 2500 TL & 61 & 38.6 \\
Between 2500TL-5000 TL & 29 & 18.4 \\
5000 TL and over & 68 & 43 \\
Total & $\mathbf{1 0 0}$ & $\mathbf{1 0 0}$ \\
\hline
\end{tabular}

\subsection{Data Analysis}

The SPSS 26.0 package program was used in the analysis of the data and the frequency, arithmetic average, standard deviation, and percentage values of the collected data were calculated.

If the distribution of scores deviates excessively, statistics that require the assumption of "normality" should not be used (Büyüköztürk, 2020). Therefore, a normality test was performed to decide which test to be performed and it was observed that the scores were not normally distributed. Table 2 shows the normality test results. 
Table 2. Normality test

\begin{tabular}{lllllll}
\hline & \multicolumn{2}{l}{ Kolmogorov -Smirnov } & \multicolumn{3}{l}{ Shapiro-Wilk } & \\
\cline { 2 - 7 } & Statistic & $\mathrm{N}$ & $\mathrm{p}$ & Statistic & $\mathrm{N}$ & $\mathrm{p}$ \\
\hline Environmental factors & .115 & 158 & .00 & .941 & 158 & .00 \\
Personal factors & .141 & 158 & .00 & .921 & 158 & .00 \\
Total & .119 & 158 & .00 & .921 & 158 & .00 \\
\hline
\end{tabular}

If the group size is greater than 50, the Kolmogorov-Smirnov test is taken into account. For a hypothesis that the distribution of scores differs significantly from the normal distribution, the p-value should be $p<.05$ (Büyüköztürk, 2020). Table 2 reveals that the distribution is not normal.

Scale interval width was calculated with the formula "range width/number of groups to be made" (Tekin, 1996). The arithmetic mean intervals used for the interpretation of the findings were determined as "1.00-1.80= Strongly Disagree", "1.81-2.60 = Disagree", "2.61-3.40 = Undecided", "3.41-4.20 = Agree", and "4.21-5.00 = Strongly Agree".

To determine the level of science anxiety of the students, the arithmetic mean and standard deviation values of the scores obtained from the SAS were calculated.

Regarding whether the anxiety scores of the students related to the science lesson make a significant difference according to the independent variables (gender, economic status, grade level, and type of school), the Mann-Whitney U-Test was conducted to understand the relationship between science anxiety levels and gender and type of school. The Kruskal Wallis H-test was used to determine the relationship between students' science anxiety levels and their grade level and the financial status of their families.

Content analysis was performed on the data collected with the anxiety form. Answers received from the students were transferred to the computer. These answers were examined by the researcher as categories and codes were created based on these answers. In the next step, the agreement coefficient was calculated based on the data coded by both researchers. The reliability of data analysis was calculated using the formula [Agreement/(Agreement + Disagreement) x 100] (Miles \& Huberman, 1994). 158 students participated in the study, but 10 of them were not evaluated as they did not respond to the anxiety form. The number of unanimous answers was evaluated as $148[148 /(148+10) \times 100=93.6]$. According to the coding control that gives internal consistency, the agreement between coders should be at least $80 \%$ (Baltac1, 2017). According to this result, the desired reliability level was reached in the study. To ensure the validity of the data collected from the research, findings representing all the codes and categories determined in detail during the data analysis phase were included. Direct quotations were made from the answers given by the students to indicate the expressions of the question along with grade level (6.G-7.G-8.G) and the number given to the students' answer sheets (S1-S2-S3...).

\section{Findings}

\subsection{Findings of the First Sub-Problem}

To find an answer to the sub-problem "What are the science anxiety levels of his students?", the arithmetic mean and standard deviation values of the total scores the students obtained from the SAS were calculated and given in Table 3.

Table 3. Average and standard deviation values of the sub-dimensions and total scores of the students according to the SAS

\begin{tabular}{llll}
\hline SAS & N & X & SS \\
\hline 1-Environmental Factors & 158 & 2.26 & .96 \\
2-Personal Factors & 158 & 2.41 & .58 \\
3-Total & 158 & 2.38 & .62 \\
\hline
\end{tabular}

Table 3 shows that the average of the total scores of the students obtained from the SAS was $X=2.38$. This result is in the range of 1.81-2.60, that is, "Disagree". According to this result, it can be stated that the science anxiety of secondary school students is close to a low level.

\subsection{Findings of the Second Sub-Problem}

The Mann-Whitney U-Test was used to find an answer to the question 'Is there a relationship between students' 
science anxiety scores and gender?", and the results are shown in Table 4.

Table 4. The Mann-Whitney U-Test results of students' sub-dimension and total score of the SAS according to gender

\begin{tabular}{lllllll}
\hline SAS & Gender & N & Mean rank & Rank sum & U & p \\
\hline Environmental factors & Female & 79 & 82.80 & 6541.00 & 2860.00 & .36 \\
& Male & 79 & 76.20 & 6020.00 & & \\
\multirow{2}{*}{ Personal factors } & Female & 79 & 77.77 & 6143.50 & 2983.50 & .63 \\
& Male & 79 & 81.23 & 6417.50 & & \\
Total & Female & 79 & 80.05 & 6324.00 & 3077.00 & .88 \\
& Male & 79 & 78.95 & 6237.00 & & \\
\hline
\end{tabular}

Table 4 shows that the personal factors, environmental factors, and total scores of the secondary school students were not related to gender $(U=2860.00, p>.05 ; U=2983.00, p>.05 ; U=3077.00, p>.05)$. However, the mean ranks show that the anxiety scores of female students were higher than male students in the environmental factors sub-dimension, that the anxiety scores of male students were higher than that of female students in the personal factors sub-dimension, and that in total, the anxiety scores of female students were higher than that of male students, but the difference was not significant.

\subsection{Findings of the Third Sub-Problem}

The Kruskal Wallis H-test was used to find an answer to the sub-problem "Is there a relationship between students' science anxiety scores and grade level?", and the results are given in Table 5.

Table 5. Kruskal Wallis H-test results of the students' sub-dimension and total score of SAS according to grade level

\begin{tabular}{llllllll}
\hline SAS & Grade level & $\mathbf{N}$ & Mean rank & sd & $\boldsymbol{\chi} \mathbf{2}$ & $\mathbf{p}$ & Significant Difference (The Mann-Whitney) \\
\hline 1-Environmental Factors & 6. & 49 & 91.76 & 2 & 11.38 & .003 & $6 . G-7 . G$ \\
& 7. & 53 & 62.77 & & & & $6 . G-8 . G$ \\
\multirow{2}{*}{ 2- Personal Factors } & 8. & 56 & 84.61 & & & & \\
& 6. & 49 & 86.02 & 2 & 1.44 & .485 & \\
3- Total & 7. & 53 & 76.58 & & & & \\
& 8. & 56 & 76.55 & & & & \\
& 6. & 49 & 88.46 & 2 & 3.90 & .142 & \\
& 7. & 53 & 70.59 & & & & \\
\hline
\end{tabular}

Table 5 shows that there was no significant difference between the students' personal factors sub-dimension of SAS and their total scores and grade levels $(\chi 2=1.44, p>.05 ; \chi 2=3.90, p>.05)$, but there was a significant difference in the environmental factors sub-dimension according to grade level $\left(\chi^{2}=11.38, p<.05\right)$. Considering the mean rank, it was determined that 6th-grade students had higher science anxiety in this sub-dimension compared to 7 th and 8th-grades.

\subsection{Findings of the Fourth Sub-Problem}

The Kruskal Wallis H-test was used to find an answer to the sub-problem "Is there a relationship between students' science anxiety scores and family income level?", and the results are given in Table 6. 
Table 6. Kruskal Wallis H-test results of the students' sub-dimension and total score of the SAS according to the economic level of the family

\begin{tabular}{|c|c|c|c|c|c|c|c|}
\hline SAS & Income & $\mathbf{N}$ & $\begin{array}{l}\text { Mean } \\
\text { rank }\end{array}$ & sd & $\mathbf{x}^{\prime}$ & $\mathbf{p}$ & Significant Difference (The Mann-Whitney) \\
\hline 1-Environmental & 2500 TL or less & 61 & 107.42 & 2 & 44.35 & .000 & *Under $2500 \mathrm{TL}-2500 \mathrm{TL}$ and $5000 \mathrm{TL}$ \\
\hline \multirow[t]{3}{*}{ Factors } & Between 2500 & 29 & 80.78 & & & & *Under 2500 TL-More than $5000 \mathrm{TL}$ \\
\hline & $\mathrm{TL}-5000 \mathrm{TL}$ & & & & & & *Between $2500 \mathrm{TL}$ and $5000 \mathrm{TL}-$ more than $5000 \mathrm{TL}$ \\
\hline & More than $5000 \mathrm{TL}$ & 68 & 53.91 & & & & \\
\hline 2-Personal & $2500 \mathrm{TL}$ or less & 61 & 97.95 & 2 & 21.13 & .000 & *Under $2500 \mathrm{TL}-$ More than $5000 \mathrm{TL}$ \\
\hline \multirow[t]{3}{*}{ Factors } & Between 2500 & 29 & 83.66 & & & & *Between $2500 \mathrm{TL}$ and $5000 \mathrm{TL}-$ More than $5000 \mathrm{TL}$ \\
\hline & TL-5000TL & & & & & & \\
\hline & More than $5000 \mathrm{TL}$ & 68 & 61.18 & & & & \\
\hline \multirow[t]{4}{*}{ 3- Total } & $2500 \mathrm{TL}$ or less & 61 & 102.65 & 2 & 33.75 & .000 & *Under $2500 \mathrm{TL}-$ Between $2500 \mathrm{TL}$ and $5000 \mathrm{TL}$ \\
\hline & Between 2500 & 29 & 85.40 & & & & *Under $2500 \mathrm{TL}-$ More than $5000 \mathrm{TL}$ \\
\hline & TL-5000TL & & & & & & *Between $2500 \mathrm{TL}$ and $5000 \mathrm{TL}-$ More than $5000 \mathrm{TL}$ \\
\hline & More than $5000 \mathrm{TL}$ & 68 & 56.22 & & & & \\
\hline
\end{tabular}

Table 6 demonstrates that the average score of the sub-dimension and total dimension of the students of the SAS show a significant difference according to the financial status of the family $\left(\chi^{2}=44.35, \mathrm{p}<.05 ; \chi^{2}=21.13, \mathrm{p}\right.$ $\left.<.05 ; \chi^{2}=33.75, \mathrm{p}<.05\right)$.

According to the results of the Mann-Whitney-U test applied to the groups in pairs to find the direction of this difference between the groups in the environmental factor sub-dimension of the SAS, a significant difference was found between those with an income less than $2500 \mathrm{TL}$ and those with an income between $2500 \mathrm{TL}$ and $5000 \mathrm{TL}$ and between those with an income more than $5000 \mathrm{TL}$ and between those with a monthly income between $2500 \mathrm{TL}$ and $5000 \mathrm{TL}$ and those with an income more than $5000 \mathrm{TL}(\chi 2=44.35, \mathrm{p}<.05)$.

Regarding the subgroup of personal factors, a significant difference was found between those with a monthly income less than $2500 \mathrm{TL}$ and more than $5000 \mathrm{TL}$, and between those with an income between $2500 \mathrm{TL}$ and $5000 \mathrm{TL}$ and more than $5000 \mathrm{TL}(\chi 2=21.13, \mathrm{p}<.05)$.

The Mann-Whitney $U$ test results show that a significant difference was found between those with an income less than $2500 \mathrm{TL}$ and those with a monthly income between $2500 \mathrm{TL}$ and $5000 \mathrm{TL}$ and those with a monthly income more than $5000 \mathrm{TL}$, and between those with a monthly income between $2500 \mathrm{TL}$ and $5000 \mathrm{TL}$ and those with an income more than $5000 \mathrm{TL}\left(\chi^{2}=33.75, \mathrm{p}<.05\right)$.

\subsection{Findings of the Fifth Sub-Problem}

The Mann-Whitney U-Test was conducted to find an answer to the sub-problem "Is there a relationship between students' science anxiety scores and type of school?", and the results are given in Table 7.

Table 7. The Mann-Whitney U-Test results of students' sub-dimension of the SAS and total score according to type of school

\begin{tabular}{lllllll}
\hline SAS & Type of school & N & Mean rank & Rank sum & U & p \\
\hline Environmental factors & Public school & 88 & 105.15 & 9253.00 & 823.00 & .000 \\
& Private school & 70 & 47.26 & 3308.00 & & \\
Personal factors & Public school & 88 & 95.59 & 8411.50 & \multirow{2}{*}{1664.50} & .000 \\
& Private school & 70 & 59.28 & 4149.50 & & \\
Total & Public school & 88 & 100.98 & 8886.50 & \multirow{2}{*}{1189.50} & .000 \\
& Private school & 70 & 52.49 & 3474.50 & & \\
\hline
\end{tabular}

It was concluded that the mean scores of the students belonging to the SAS showed a significant difference according to type of school $(\mathrm{U}=823.00, \mathrm{p}<.05 ; \mathrm{U}=1664.50, \mathrm{p}<.05 ; \mathrm{U}=1189.50, \mathrm{p}<.05)$. The rank-sum also shows that the anxiety level of the students studying in private school was low in all three dimensions according to type of school.

\subsection{Findings of the Sixth Sub-Problem}

The content analysis was conducted to search for an answer to the sub-problem "What are the students' anxieties about the science lesson?" along with the analysis of the data collected and these results were interpreted. 
Situations that mostly make students anxious about science lessons are shown in Table 8 .

Table 8. Results of content analysis regarding students' anxiety about the science lesson

\begin{tabular}{|c|c|c|c|c|c|}
\hline Categories & $\mathbf{F}$ & $\%$ & Codes & $\mathbf{F}$ & $\%$ \\
\hline \multirow[t]{5}{*}{ The science lesson-based } & 47 & 31.7 & Examination & 30 & 20.2 \\
\hline & & & Rote learning & 9 & 6.1 \\
\hline & & & Hardness & 5 & 3.3 \\
\hline & & & Falling behind & 2 & 1.3 \\
\hline & & & Homework & 1 & 0.7 \\
\hline \multirow[t]{3}{*}{ Environmental factors-based } & 38 & 25.7 & Entourage & 29 & 19.7 \\
\hline & & & Physical environment & 6 & 4 \\
\hline & & & Home environment & 3 & 2 \\
\hline Nothing & 22 & 14.9 & Nothing & 22 & 14.9 \\
\hline \multirow[t]{2}{*}{ Teacher-based } & 20 & 13.5 & The attitude of the teacher & 11 & 7.4 \\
\hline & & & Asking questions & 9 & 6.1 \\
\hline \multirow[t]{4}{*}{ Student-based } & 17 & 11.5 & Giving wrong answers to questions & 7 & 4.7 \\
\hline & & & Failing to answer & 4 & 2.7 \\
\hline & & & Attitude & 1 & 0.7 \\
\hline & & & Morale & 1 & 0.7 \\
\hline Everything & 5 & 3.4 & Everything & 5 & 3.4 \\
\hline Future anxiety & 2 & 1.3 & Good school & 2 & 1.3 \\
\hline Anxiety in the past & 1 & 0.7 & Experience & 1 & 0.7 \\
\hline
\end{tabular}

According to the results in Table 8, $47(31.7 \%)$ of the secondary school students who participated in the study stated that their anxiety about the science lesson is lesson-based. $30(20.2 \%)$ of the students who expressed their opinions in this line stated that the examination makes them anxious. 9 of the students $(6.1 \%)$ stated that the rote learning-based worries them, while 5 of the students (3.3\%) stated that the lesson is hard for them. $2(1.3 \%)$ of the students stated that they were worried that they would fall behind the lesson, and $1(0.7 \%)$ of the students stated that they were worried about the homework. Statements of some participants regarding this category are given below.

"The examination worries me because no matter how hard I work, I cannot do it." (6.G-S55)

"The examination is hard because I have difficulties sometimes and this makes me worried." (6.G-S58)

"Some subjects are difficult for me and this is why I worry when I don't understand." (6G-S62)

"I am worried as the lesson is based on rote learning and I cannot memorize some parts." (7.G-S45)

"Examinations are a source of anxiety for me because they are crucial in the report card." (7.G-S41)

"Some science topics make me anxious because some science topics may confuse me as logic and interpretation-based questions are asked to me, in this case, it worries me." (8.G-S13)

"Getting results under 60 from the examination worries me because my family gets angry." (8.G-S9)

"There are very difficult formulas, and I am worried that I cannot memorize them." (8.G-S6)

"I love the science lesson, but examinations worry me." (8.G-S86)

"Sometimes I fall behind because I am inevitably lost in the class, and I worry about falling behind." (8.G-S89)

"As the lesson is based on rote learning, concepts and formulas worry me. Thus, I am having a lot of difficulties. (8.G-S78)"

"The examinations worry me because I am not good at science." (6.G-S137)

According to the results in Table 8,38 students $(25.7 \%)$ of the secondary school students participating in the study stated that their anxiety about the science lesson is caused by environmental factors. $29(19.7 \%)$ of the students whose anxiety about the science lesson is caused by environmental factors is based on their entourage. While $6(4 \%)$ of the students stated that the physical environment worries them, $3(2 \%)$ of the students stated that the physical environment at home worries them. Statements of some participants regarding this category are given below.

"The broken glass of the classroom worries me because I cannot focus on the lesson." (7.G-S51) 
"I am afraid of being embarrassed in the classroom when I forget the subject and fail to answer" (7.G-S36)

"I am interested in the lesson, especially in some subjects, but what disturbs $\mathrm{m}$ is to be in the society and thus, this environment also worries me." (8.G-S25)

"I am worried that my friends will make fun of me." (8.G-S77)

"Watching TV and having sound around while studying at home is what worries me because I cannot focus on and understand what I am studying." (6G-S69)

"I'm afraid to answer the question because my friends may make fun of me." (8.G-S65)

"My classmates nickname me, and so I don't want to participate in the class." (8.G-S71)

"Sometimes my friends make fun of me when I don't know how to answer the questions." (8.G-S78)

"When I answer the question incorrectly, I am afraid that all of my friends will shout all together "wrong"."

"I am afraid of getting into a difficult situation. Maybe the class will laugh at me when I say something." (6.G-S138)

According to the results in Table 8, 22 students (14.9\%) of the secondary school students participating in the study stated that they do not have any concerns about the science lesson. Statements of some participants regarding this category are given below.

"I have no worries in the science lesson because our teacher teaches very well." (7.G-S35)

"I have no worries because our science teacher is excellent." (7.G-S52)

"I never worry in the science lesson because I love science lessons very much and I do not worry because I study hard" (6.G-S57)

"Thanks to our teacher, I understand the lesson very well, and thus, I have no worries at all." (7.G-S48)

"I have no worries because our teacher is the queen. I love her very much. I love the science lesson because of this teacher." (8.G-S20)

"Nothing is worrying me about the science lesson because I think I study regularly." (6.G-S67)

"I love the science lesson and I love my teacher very much. The science lesson should definitely be given and I don't worry about anything." (8.G-S88)

"I am not afraid of the science lesson, it is a very enjoyable lesson for me, and my teacher teaches it very well. I have no complaints about the science lesson. In the past, it was embarrassing that my friends looked at me when I raised my finger a little and it is over now, so I am very happy." (6.G-S139)

According to the results in Table 8, 20 (13.5\%) of the secondary school students who participated in the study stated that their anxiety about the science lesson is teacher-based. $11(7.4 \%)$ of the students stated that they are worried about the attitude of the teacher, while $9(6.1 \%)$ stated that they are worried because of questions asked by the teacher. Statements of some participants regarding this category are given below.

"I am worried to see that the teacher gets angry with me when I fail to answer the question, and my teacher gets sad and disappointed with my bad results, and when I fail to hand in my assignments. That's why I feel very unsuccessful and sorry, and I am not fussed about studying." (7.G-S40)

"I am anxious when the teacher asks me questions because I can easily forget some information." (8.G-S23)

"When I do not understand the subject, I am afraid that the teacher will ask me questions about the relevant subject." (8.G-S21)

"I am anxious when the teacher asks questions because when I am asked a question, I am afraid that others will laugh at me if my answer is ridiculous and funny." (8.G-S15)

"I worry about the reaction of the teacher when I fail to answer a question in class." (8.G-S1)

"I am concerned about giving an answer to questions though I know the exact answer because I cringe before the teacher." (8.G-S90)

"When I fail to answer the question, it worries me to see the teacher glaring at me." (6.G-S154)

According to the results in Table 8 , it has been determined that $13(8.8 \%)$ of the secondary school students participating in the study have student-based anxiety about the science lesson. $7(4.7 \%)$ stated that answering the questions incorrectly worries them, $4(2.7 \%)$ are worried as they fail to answer the questions, and $1(0.7 \%)$ 
are worried because of their attitude towards the lesson. And $1(0.7 \%)$ stated that the science lesson worries $\mathrm{him} / \mathrm{her}$ when s/he is depressed. Statements of some participants regarding this category are given below.

"Not being able to answer the question asked by the teacher worries me because my teacher thinks I have no idea about it." (7.G-S53)

"It makes me anxious when I hesitate to answer a question which I surely can answer in the examination at that moment." (7S-S54)

"I don't like the lesson, so the lesson worries me." (7.G-S39)

"Not having a good command of a subject of the science lesson worries me because I think I may fall out of favour of the teacher." (8.G-S24)

"Although I understand the subject, I cannot answer the questions in tests." (8.G-S22)

"Giving wrong answers to distracters worries me because it makes me sad when I fail though I am fully convinced that I know the subject." (8.G-S19)

"Actually, I am not afraid of most things about science, I am embarrassed only when I cannot get a bad grade or answer a question in the science lesson, and sometimes I am confused when I do not understand anything." (6.G-S70)

"I am anxious when I am not happy because being unhappy makes me feel tired. Therefore, I don't understand the lesson and become anxious." (6.G-S66)

"When being asked a question, I am afraid that I will answer the question wrong." (8.G-S91)

"Although I study for exams, I am afraid that I will get stressed during exams." (8.G-S97)

According to the results in Table 8, 5 (3.4\%) of the secondary school students participating in the study stated that everything worries them about the science lesson. Statements of some participants regarding this category are given below.

"Everything related to the science lesson worries me." (8.G-S4)

"I do not like the lesson at all, everything about it scares me." (8.G-S101)

According to the results in Table 8, $2(1.3 \%)$ of the secondary school students participating in the study stated that they have concerns about the future. One of the students $(0.7 \%)$ stated that he/she has concerns about the science lesson from previous years. Statements of some participants regarding this category are given below.

"The most anxious thing is to get bad results in examinations because if I get bad exams, the chance of going to a good high school decreases." (7.G-S47)

"Sometimes I worry that the teacher will ask questions because when I was in lower grades, in the 4th or 3rd-grade, the teacher got angry with me because of the questions I could not answer." (8.G-S72)

"If I fail the science lesson now, I am afraid that I will not be able to do it in the future." (6.G-S132)

\section{Discussion and Conclusion}

It has been determined in the study that the total anxiety average of the students was $\mathrm{X}=2.38$ and at the level of "1.81-2.60 = Disagree". Results suggest that the science anxiety level of the students is low. Literature review reveals that similar results have been obtained in other studies. Akça (2017) found that the science anxiety levels of 4th, 5th, 6th, 7th, and 8th-grades are low. Similarly, Oskay (2019) and Şahin and Kaya (2020) also found that it was "low". There are also studies on the anxiety score and the attitude towards the lesson. Kağıtç1 (2014) examined whether there is a significant relationship between students' scores of anxiety about the science lesson and their attitudes towards this lesson. As a result of the study, it has been shown that there is a moderate, negative, and significant relationship between the students' scores of anxiety about the science lesson and their attitude scores towards this lesson. In their study, Kahyaoğlu, Birel and Yetişir (2019) determined that there was a significant negative relationship between self-learning planning skills and confidence skills in science lessons and science anxiety levels. They also stated that as science anxiety levels of secondary school student's increase, their ability to plan self-learning and confidence in science lessons decreases.

In the study, no significant difference was found between the scores of sub-factors and total scores of the SAS in terms of gender variable. Similarly, it was shown that there was no relationship between anxiety scores and gender in their studies (Yenilmez \& Özbey, 2006; Aydın, Delice, Dilmaç, \& Ertekin, 2009; Kağıtçı, 2014; Akça, 2017). On the other hand, Yolagiden and Bektaş (2018) found in their study that there was a significant difference between eighth-grade students' science anxiety and gender, and the science anxiety of male students 
was higher than that of female students.

In the study, no significant difference was found in the personal factors sub-dimension of SAS and the total scores of secondary school students in terms of grade level. However, it has been determined that there is a significant difference in the environmental factors sub-dimension of the SAS of the students according to grade level variable. Considering the mean ranks, it has been determined that 6th-grade students have higher science anxiety in this sub-dimension compared to 7 th and 8th grades. In addition, it was determined that 8th-graders have higher anxiety scores in the environmental factor sub-dimension than 7th-graders, but this difference is not significant. Considering the answers given by the students to the questions in the environmental sub-dimension, the 6th-graders' responses to the item "I worry that the teacher will ask questions" and "I have to study while watching TV or talking to others in the room" by the 6th-graders show that they have higher anxiety than other grades. It can be thought that 6th-grade students have such anxiety as part of their developmental period. This may be because the parents do not take the situation of the students very seriously since 6th-graders are not subjected to examinations of highly critical importance. In particular, these two items explain the reason why the anxiety of 6th-graders is high in environmental sub-dimension. Sirmac1 (2007) determined in his study that there is a relationship between grade level and anxiety scores. Oskay (2019) also found significant differences according to grade level in the total score of anxiety about avoidance of lesson and the science lesson and of the scale. On the other hand, Yenilmez and Özabacı (2003), Yenilmez and Midilli (2006), Yenilmez and Özbey (2006), Kağıtçı (2014) and Akça (2017) found that there was no relationship between grade level and anxiety scores.

It has been determined that there is a statistically significant difference between the sub-dimensions and total score averages of the secondary school students according to the financial status of the family. Considering the mean ranks, and where the anxiety level is ranked from lowest to highest, it is obvious that as the economic level improves, the level of anxiety decreases. It has been determined that the families of the students with the highest anxiety have a monthly income of $2500 \mathrm{TL}$ and below. According to MEB (2018), "the socioeconomic level is one of the factors that have a great impact on students' access to resources in terms of academic and educational development." Families with good financial status can offer them more opportunities for their children's education. It can be concluded that dealing with educational problems and the ability to give them all kinds of support not only may support children but also their anxiety about the science lesson may decrease. In this respect, students whose fathers are civil servants are economically more comfortable and have lower anxiety levels. Yolagiden and Bektaş (2018) investigated the relationship between science learning anxiety and the socioeconomic level of the family, concluding that there is a significant difference between both issues. In this case, students with high anxiety are not able to meet their needs fully with feelings of dissatisfaction, insufficiency, and insecurity (Çakmak \& Hevedanl1, 2004; Yolagiden \& Bektaş, 2018). Similarly, some studies (Girgin, 1990; Aral, 1997; Karabulut, 2018) show that there are differences according to the socioeconomic level and the anxiety levels of the students and that the anxiety levels of children in families with low socioeconomic levels are high.

It was concluded that the mean scores of the sub-dimensions and total dimensions of the science anxiety scale of secondary school students showed a statistically significant difference according to type of school. While one of the schools where the study was conducted is a village school in the province of Siirt, the other is a private school located in the centre of Siirt. The mean rank revealed that the anxiety level of the students studying in a private school is low in all three dimensions according to type of school. Based on this result, it is thought that this difference is caused by the education provided in schools, the teacher approach, being able to reach the opportunities, the teaching methods and material diversity used in the lessons, the laboratory facilities, and the friend factors. Similarly, Gömleksiz and Yüksel (2003) found in their study that the anxiety scores of students attending a public school are higher than those who study at a private school. They also emphasized that schools are becoming more important and may not be replaced by any technology in the future and in addition, the changing functions of schools should not be ignored. On the other hand, Karabulut (2018) stated in his study that the anxiety scores of 5th-grade students in public secondary school and 5th-grade students in a private secondary school did not make a significant difference in terms of type of school variable.

An interview form was used to determine the anxiety of secondary school students about the science lesson. As a result of the analysis of the collected data, it was determined that students' anxiety about the science lesson depends on six main reasons, among which are anxiety about the future, the science lesson, environmental factors, the teacher, the student himself, and anxiety in the past. Some students stated that nothing worried them, while some others stated that everything related to the science lesson worried them.

Another important factor that worries students in science lessons is the anxiety caused by environmental factors. 
In this category, $29(19.7 \%)$ are anxious due to their entourage, $6(4 \%)$ due to the physical environment, and 3 $(2 \%)$ due to the home environment. Based on a descriptive analysis of the 19th-item in the questionnaire which reads: "I am afraid of falling into an embarrassing or difficult situation in science lessons", it was determined that $24(15.2 \%)$ students responded as "Strongly agree" and $19(12 \%)$ as "Agree". According to the results, qualitative and quantitative data are close to each other. Results of the environmental factors reveal that a significant number of students have anxiety about expressing themselves in front of others in the classroom as they believe they will be mocked or fall into a difficult situation.

Twenty (13.5\%) of the students stated that they have concerns about the teacher. The students are mainly concerned about the teacher's attitude (7.4\%) and being asked questions (6.1\%). The descriptive analysis shows that $40(25.3 \%)$ responded as "Strongly agree", and $14(8.9 \%)$ as "Agree". According to the descriptive analysis of the 5th-item which reads: "I worry that the teacher will ask questions in the science lesson", $15.2 \%$ of the students responded as "Strongly agree" and $5.7 \%$ as "Agree". The results of qualitative research demonstrate that the attitude of the teacher causes worries more than questions asked by the teacher. Kaya and Yildirım (2014) conducted semi-structured interviews with six 9th-grade students who failed in chemistry lesson to investigate the sources of science anxiety of unsuccessful students in their study, concluding that the source of science anxiety in students was variables such as perceptions of chemistry, the attitudes of teachers and families, fear of tests, and boring classroom activities. Similarly, Say and Uçak (2019) found that students were concerned about the attitudes and questions of the teacher.

Another factor that worries students in the science lesson is the anxiety caused by the student himself. $4.7 \%$ of the students stated that they are afraid of answering the questions incorrectly and thus are anxious, $2.7 \%$ are worried about failing to answer, $0.7 \%$ are anxious due to their attitude towards lesson, and $0.7 \%$ are anxious due to depression. The descriptive analysis of the 21 st-item which reads: "I have no self-confidence in learning science" makes it clear that $13(8.2 \%)$ responded as "Strongly agree", while $8(5.1 \%)$ responded as "Agree". It is understood that quantitative and qualitative data are close to each other. Responses to the 13th-item as "I do not feel competent enough to solve the questions about science", are said "Strongly agree" by 21 of the students $(13.3 \%)$ and "Agree" by 13 (8.2\%). One may notice that a small portion of the students do not feel self-confident enough and feel incompetent to answer the questions. However, there is a slight difference between the qualitative and quantitative data in that students' primary concerns are from other sources since they are asked to write about the most anxious factor in the qualitative part.

Twenty-two (14.9\%) of the students stated that they have no worries about the science lesson. However, $3.4 \%$ of the students stated that everything related to the science lesson worries them. In addition, it has been determined that $1.3 \%$ of the students are worried about the future, which is mainly related to being enrolled in a good school. And only $1(0.7 \%)$ of the students is concerned about the anxiety in the past.

\section{Recommendations}

It is revealed in the research that type of school has a crucial role in science anxiety. Facilities in schools need to be increased and improved in terms of materials and laboratory materials used. In addition, it can be thought that conducting lesson activities to reduce science anxiety in lessons may also reduce anxiety. In this study, it was understood from the responses to the item in the questionnaire revealing that the students do not have anxiety about the science laboratory. Based on these findings, students should be encouraged to spend more time in the science laboratory.

It has been determined that the economic level of families has a significant effect on students' science anxiety and as the economic situation improves, the student's anxiety decreases. Families play a crucial role in the relevant issue. Families with poor economic conditions should not reflect their situation to the student. It should be kept in mind that problems at home directly affect students. In this regard, having interviews with parents at certain intervals may help reduce anxiety. In addition, seminars and courses by education experts and academicians can be organized for students and parents.

To reduce the anxiety caused by the science lesson, the subjects that students have difficulty in learning should be determined, notably rote learning-based subjects, and the lessons should be taught in a way for meaningful learning by removing the subjects from being based on rote learning. One of the most anxious factors for students is concerns about examinations. At this stage, it is thought that it would be beneficial to ask questions in a way that may improve the interpretation skills of the students instead of the questions that require memorization. Different evaluation methods can be used in examinations as much as possible. At the same time, the teacher can enrich the lesson with various teaching methods. It can be said that using student-centred teaching methods, techniques and strategies may also reduce anxiety. 
In this research, it has been determined that students have serious concerns about their friends in the classroom. It is thought that making the classroom environment more democratic and preparing a classroom atmosphere where students can easily express their opinions may also reduce anxiety. Teachers in the field of classroom control and management also have a lot of work to do. In this context, it can be thought that classroom discussions about the subject or warnings for students in certain situations may also reduce anxiety. In addition, all students should be involved in the lesson and students should communicate effectively with each other.

The reasons for the teacher-based anxiety should be determined by the teacher himself. Teachers should be aware of their shortcomings regarding the subject. It has been determined in various studies that even if the students do not worry, the attitude and questions of the teacher worry the students. It is inferred from the results of this study that the teachers should behave equally to all students, respect their ideas, and be more careful while using the tone of their voice by considering the developmental characteristics of the students. And acting constructively rather than reprimanding may reduce anxiety.

Students who have anxiety about themselves and the science lesson due to their experiences in the past can be identified, and anxieties about this situation can be reduced by providing effective guidance services. Encouraging and uplifting activities can be done for these students.

This study also includes questions about demographic characteristics, grade, gender, type of school, and the financial situation of the family. In addition, the effects of other factors on anxiety may be investigated.

This study was conducted with the 6th, 7th, and 8th-grades of secondary school. Similar studies can be carried out with students from other grades, and science anxiety can be detected at an early age and necessary measures can be taken. Similarly, these types of studies can be done with parents, teachers, and school administrators.

Other studies are composed of qualitative as well as quantitative studies, and there are no studies in which both were used together. The number of such studies should increase to determine the causes of the anxiety of students in more detail and to prevent the factors of anxiety.

Similar studies to be carried out are also important in terms of determining the causes of the anxiety of students and taking necessary precautions by applying them in different cities and different types of schools in Turkey.

This study took into consideration only anxiety about the science lesson. In addition to science anxiety, studies such as science and mathematics anxiety can be conducted regarding anxiety in other lessons and in terms of various variables.

\section{References}

Akça, B. (2017). Ortaokul ögrencilerinin fene yönelik zihinsel risk alma davranışları ile fen kaygıları arasındaki ilişkinin belirlenmesi. Yüksek Lisans Tezi. Adnan Menderes Üniversitesi. Aydın.

Akçöltekin, A., \& Doğan, S. (2013). İlköğretim 6. sınıf öğrencilerinin fen bilgisi dersine ilişkin kaygılarının farklı değişkenler açısından incelenmesi. The Journal of Academic Social Science Studies, 6(2), 13-29.

Aral, N. (1997). Fiziksel İstismar ve Çocuk. Ankara: Tek Iş̧1k Veb Ofset Tesisleri.

Aydın, E., Delice, A., Dilmaç, B., \& Ertekin, E. (2009). İlköğretim matematik öğretmen adaylarının matematik kaygı düzeylerine cinsiyet, sınıf ve kurum değişkenlerinin etkileri. İlköğretim Online, 8(1), 231-242.

Baltac1, A. (2017). Nitel Veri Analizinde Miles-Huberman Modeli. Ahi Evran Üniversitesi Sosyal Bilimler Enstitüsü Dergisi (AEÜSBED), 3(1), 1-15.

Büyüköztürk, Ş. (2008). Sosyal Bilimler İçin Veri Analizi El Kitabı: İstatistik, Araştırma Deseni SPSS Uygulamaları ve Yorum. Pegem A Yayıncılık, Ankara.

Deveci, E. S., Çalmaz, A., \& Açık, Y. (2012). Doğu Anadolu'da yeni açılan bir üniversitenin öğrencilerinde kaygı düzeylerinin sağlık, sosyal ve demografik faktörler ile ilişkisi. Dicle Tip Dergisi, 39(2).

Diken, E. H. (2018). Fen bilgisi öğretmenleri ile 8. Sinıf öğrencilerinin temel eğitimden ortaöğretime geçiş (TEOG) sınavındaki kaygılarına yönelik görüşleri (Kars İli Örneği). İnsan ve Toplum Bilimleri Araştırmaları Dergisi, 7(2).

Eddy, R. M. (2000). Chemophobia in the college classroom: Extent, sources, and students characteristics. Journal of Chemical Education, 77(4), 514-517.

Girgin, G. (1990). Farklı sosyo ekonomik kesimden 13-15 yaş grubu ögrencilerinde kaygı altınları ve kaygl düzeyinin başarıyla iliş̧kisi. Yayımlanmamış yüksek lisans tezi, Dokuz. Eylül Üniversitesi, İzmir.

Gömleksiz, M. N., \& Yüksel, Y. (2003). Illköğretim 4. Ve 5. Sinıf öğrencilerinin fen bilgisi dersine ilişkin 
kaygıları. Doğu Anadolu Bölgesi Araştırmaları 3.

Güzeller, C. O., \& Doğru, M. (2011). Development of Science Anxiety Scale for Primary School Students. Soc Indic Res.

Hazır, A. (2006). İlköğretim 5. Sinıf Öğrencilerinin Bilimsel Süreç Becerilerini Edinebilme Düzeyleri. Yüksek Lisans Tezi. Afyon Kocatepe Üniversitesi Sosyal Bilimler Enstitüsü, Afyonkarahisar.

Hill, K. T., \& Sarason, S. B. (1966). The relation of test anxiety and defensiveness to test and school performance over elementary school years: a further longitudinal study. Monogr Soc Res Child Dev., 31(2), $1-76$.

Kağıtçı, B. (2014). Fen dersine yönelik kaygı ölçeği gelişstirilmesi ve ortaokul öğrencilerinin fen dersi kaygı ile tutum puanlarının çeşittli değişkenlere göre incelenmesi. Yüksek Lisans Tezi. Sakarya Üniversitesi, Sakarya.

Kahyaoğlu, M., Birel, F. K., \& Yetişir, M. İ. (2019). Ortaokul öğrencilerinin fen bilimleri derslerine yönelik kendi kendine öğrenme becerilerinin yordanmasında kaygının rolü. Elektronik Sosyal Bilimler Dergisi, 18, 69.

Karabulut, B. (n.d.). Ortaokul 5. sinıf öğrencilerinin Fen bilimleri dersine yönelik Kaygllarının incelenmesi. Yüksek Lisans Tezi. Fırat Üniversitesi Eğitim Bilimleri Enstitüsü Matematik ve Fen Bilimleri Eğitimi Anabilim Dalı Fen Bilgisi Eğitimi Bilim Dalı. Elazı ̆

Kaya, E., \& Yıldırım, A. (2014). Science anxiety among failing students. Elementary Education Online, 13(2), $518-525$.

Laukenmann, M., Bileicher, M., Fu, S., Glaser-Zikuda, M., Mayring, P., \& Von Rhöneck, C. (2003). An investigation of the influence of emotional factors on learing in physics instruction. International Journal of Science Education, 25(4), 489-507.

Mallow, J. (1988). Science Anxiety, Fear of Science and How to Overcome It. American Journal of Physics, $56(7), 670$.

MEB. (2018). İlköğretim kurumları Fen Bilimleri dersi öğretim programı. Ankara: Talim ve Terbiye Kurulu Başkanlığı.

Miles, M. B., \& Huberman, A. M. (1994). Qualitative data analysis. Thousand Oaks, CA: Sage.

Morgan, C. T. (1991). Psikolojiye giriş (Ed. Sibel Karakaş). Ankara: Hacettepe Üniversitesi Yayınları.

Oğuz, A., \& Karakuş, G. (2017). Öğretmen adaylarının öğrenme yaklaşımları ile kaygı düzeyleri arasındaki ilişkinin incelenmesi. Journal of Human Sciences, 14(2).

Oludipe, D., \& Awokoy, J. O. (2010). Effect of cooperative learning teaching strategy on the reduction of students' anxiety for learning chemistry. Journal of Turkish Science Education, 7(1).

Oskay, S. (2019). Ortaokul ögrencilerinin motivasyonel, bilişsel Ve bilişüstü yeterlikleri ile fen bilimleri dersine yönelik tutum ve kaygıları. Yüksek Lisans Tezi. Bolu Abant İzzet Baysal Üniversitesi Eğitim Bilimleri Enstitüsü Eğitim Bilimleri Anabilim Dalı Eğitim Programları Ve Öğretim Bilim Dalı.

Sağır, U. Ş. (2014). Illköğretim öğrencilerine yönelik fen kaygı ölçeği. Buca Eğitim Fakültesi Dergisi 37.

Şahin, F. Y. (2000). Matematik kaygısı. Eğitim Araştırmaları Dergisi, 1(2), 75-79.

Şahin, M., \& Kaya, H. (2000). Ortaokul Öğrencilerinin Fene Yönelik Kaygı Düzeylerinin Farklı Değişkenler Açısından İncelenmesi. Academia Eğitim Araştırmaları Dergisi, 5(2).

Seçer, İ. (2017). SPSS ve LISREL ile Pratik Veri Analizi. Ankara: Anı yayınc1lı.

Uçak, E., \& Say, S. (2019). Ortaokul öğrencilerinin fen dersine yönelik kaygı nedenlerinin incelenmesi. Mehmet Akif Ersoy Üniversitesi Ĕ̈itim Fakültesi Dergisi, 50, 71-89.

Yenilmez, K., \& Midilli, P. (2006). İlköğretim Öğrencileri ve Velilerinin Matematik Kaygı Düzeyleri. Eskişehir Osmangazi Üniversitesi Sosyal Bilimler Dergisi, 7(2), 97-112.

Yenilmez, K., \& Özbey, N. (2006). Özel okul ve devlet okulu öğrencilerinin matematik kaygı düzeyleri üzerine bir araştırma. Uludağ Üniversitesi/Eğitim Fakültesi Dergisi, 19(2), 431-448.

Yolagiden, C., \& Bektaş, O. (2018). Sekizinci Sınıf Öğrencilerinin Fen Bilimleri Öğrenme Kaygıları ile Fen Bilimleri Öğrenme Yönelimleri Arasındaki İlişkinin İncelenmesi. Uluslararası Eğitim Bilimleri Dergisi, 2(2), 18. 


\section{Copyrights}

Copyright for this article is retained by the author, with first publication rights granted to the journal.

This is an open-access article distributed under the terms and conditions of the Creative Commons Attribution license (http://creativecommons.org/licenses/by/4.0/). 